\title{
PERKEMBANGAN PERBANKAN BAGI HASIL DI INDONESIA
}

\author{
Wikan Budi Utami
}

STIE AAS Surakarta

\begin{abstract}
ABSTRAK
Anjloknya nilai tukar mata ung lokal yang diakibatkan adanya krisis ekonomi, menyebabkan bank-bank konvensional yang memberlakukan sistem bunga dan menganggap uang bukan hanya sekedar berfungsi sebagai alat tukar melainkan telah menjadi barang komoditas, sehingga mereka menaikkan secara besar-besaran bunga pinjaman dan simpanannya. Tingginya tingkat bunga tersebut menyebabkan ekonomi kekurangan likuiditas, yang akibatnya dunia usaha menjadi stagnan, sehingga akhirnya bangkrut dan berakibat meningkatnya pengangguran. Walhasil masyarakat semakin miskin. Di sisi lain bank harus membayar bunga deposito yang tinggi, sedangkan pendapatan bunganya anjlok karena kredit macet. Akhirnya banyak bank-bank konvensional berbasis bunga, satu per satu gugur terlikuidasi. Dalam keadaan demikian terbukti bank syariah yang non bunga tapi bersistem bagi hasil (profit sharing)-lah yang bisa tetap bertahan terhadap tekanan krisis ekonomi. Hal ini disebabkan karena konsep yang mendasari sistem keuangan syariah, menganggap uang hanya sebagai alat tukar. Sehingga uag tersebut tidak akan menghasilkan nilai tambah apapun, kecuali apabila dikonversi menjadi barang atau jasa. Sehingga tiap transaksi keuangan harus dilatarbelakangi transaksi sektor riil.
\end{abstract}

Kata kunci : perbankan, bagi hasil

\section{PENDAHULUAN}

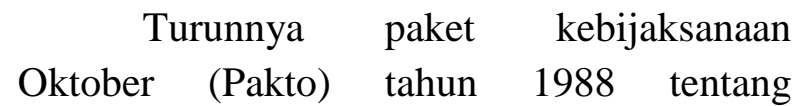
liberalisasi industri perbankan, yang pada intinya memudahkan seseorang untuk mendirikan sebuah bank, bahkan dengan uang kurang dari seratusjuta maka seseorang sudah bisa mendirikan bank. Sehingga pada akhirnya banyak bank-bank baru bermunculan tanpa kendali seperti tumbuhnya jamur dimana-mana tanpa diimbangi dengan sumber daya manusia (SDM) yang memadai. Hingga sampai awal Juli 1997 Indonesia Jurnal IImiah Ekonomi Islam - Vol. 01, No. 01, Maret 2015 dilanda krisiis ekonomi, yang berawal dari gejolak moneter di negara-negara tetangga, sehingga nilai tukar rupiahpun terdepresiasi besar, nilai tukar uang lokal anjlok. Pada keadaan demikian hampir semua bank menaikkan suku bunga simpanan dan pinjamamnya. Akibatnya, pengusaha yang membutuhkan/memiliki pinjaman akan dibebani bunga yang sangat besar. Sehingga jumlah yang harus mereka bayarkan menjadi sangat besar. Bahkan lebih besar dibandingkan laba yang diperolehnya. Beban bunga yang demikian tinggi tersebut tidak 
mungkin terpikul oleh pengusaha. Namun karena pengusaha memerlukan likuiditas, kredit bunga tinggi itu diambilnya juga.

Tahap berikutnya adalah bank-bank yang mengalami kredit macet dengan jumlah besar satu-persatu terancam eksistensinya, karena di satu sisi bank membayar bunga deposito yang sangat tinggi, sedang pendapatan bunganya anjlok karena kredit macaet. Agaknya hal tersebut saat ini belum berhasil sembuh, meskipun sudah dirawat di Badan Penyehatan Perbankan nasional (BPPN), sehingga akhirnya beberapa bank dilikuidasi.

Dalam keadaan krisis tersebut ternyata lembaga keuangan yang masih eksis dan fleksibel dalam keadaan moneter yang semakin menurun adalah sebuah bank yang tidak menerapkan sisitim bunga, tapi sistim yang digunakan adalah bagi hasil (profit and loss sharing), yaitu bank syariah. Sistim perbankan syariah memang memungkinkan hal demikian terjadi berkat sisitim bagi hasil yang mereka terapkan dalam mengelola usaha.Itu pula yang membuat kepercayaan nasabah terusmeningkat.

\section{AWAL KELAHIRAN SISTEM PERBANKAN SYARIAH}

Menurut PP No. 72/1992,yang dimaksud bank bagi hasil adalah bank yang sistim operasinya berdasarkan pada sistim syariah. Walaupun berbau Islam, sebenarnya konsep bank syariah sangat universal dan juga ditujukan unutk seluruh kalangan, bukan hanya untuk kalangan muslim saja.

Sejak awal kelahirannya perbankan syariah dilandasi dengan kehadiran dua gerakan renaissance Islam modern: neorevivalis dan modernis (Saeed, 1996). Tujuan utama dari pendirian lembaga keuangan berlandaskan etika ini adalah tiada lain sebagai upaya hukum kaum muslimin untuk mendasari segenap aspek kehidupan ekonominya berdasarkan Al -Qur'an dan AsSunnah.

Upaya awal penerapan sisitim profit dan loss sharing tercatat di Pakistan dan Malaysia sekitar tahun 1940-an, yaitu adanya upaya mengelola dana jamaaah haji secara non konvensional. Rintisan institusional lainnya adaah Islamic Rural Bank di desa Mit Ghamr pada tahun 1963 di Kairo, mesir. Setelah dua rintisan yang cukup sederhana itu,Bank Islam tumbuh dengan sangat pesat. Sesuai dengan analisa Prof. Khursid Ahmad dan laporan International AAssociation of Islamic Bank,hingga akhir 1999 tercatat lebih dari dua ratus lembaga keuangan Islam yang beroperasi di seluruh dunia, baik di negaranegara berpenduduk muslim maupun di Eropa,Australia, dan Amerika kata Khursid dalam Ahmad (1999)

Suatu hal yang juga patut dicatat adalah saat ini banyak nama besar dalamdunia keuangan internasional seperti Citibsak, Jardine Fleming, ANZ, Chase Chemical Bank, Goldman Sach dan lain-lain telah 
membuka cabang dan subsidiaries yang berdasarkan syariah. Dalam dunia pasar modalpun, Islamic fund kini ramai diperdagangkan, suatu hal yang mendorong singa pasar modal dunia Dow Jones untuk menerbitkan Islamic Dow Jones Index. Sehingga tak heran jika Scharf, mantan direktur utama bank Islam Denmark yang non muslim itu, menyatakanbahwa Bank Islam adalah partner baru pembangunan.

\section{PERKEMBANGAN BANK SYARIAH DI INDONESIA}

Perkembangan bank-bank syariah di negara-negara Islam berpengaruh di Indonesia. Pada awal periode 1980-an, diskusi mengenai bank syariah sebagai pilar ekonomi Islam mulai dilakukan. Para tokoh yang terlibat dalam kajian tersebut adalah Karnaen a.perwataatmadja, M. Dawam Raharjo, A.M.Saefudin. M. Amien Azis dan lain-lain (Azis 1992). Beberapa uji coba pada skala yang relative terbatas telah diwujudkan. Di antaranya adalah Baitul Tamwil Salman, bandung, yang sempat tumbuh mengesankan. Di Jakarta juga dibentuk lembaga serupa dalam bentuk koperasi, yaitu Koperasi Ridho gusti. Namun prakasa lebih khusus untuk mendirikan bank bank Islam di Indonesia baru dilakukan pada tahun 1990. Majelis Ulama Indonesia (MUI) pada bulan Agustus 1990 telah menyelenggarakan Lokakarya Bunga Bank dan Perbankan di Cisarua Bogor jawa Barat. Hasi lokakaryatersebut dibahas kembali dalam Musyawarah Nasional IV
MUI, dan dihasilkan kelompok kerja untuk mendirikan bank Islam di Indonesia. Kelompok kerja yang disebut Tim Perbankan MUI, bertugas melakukan pendekatan dan konsultasi dengan semua pihak terkait.

Pada tahap selanjutnya, bank syariah yang lahir pertama di Indonesia adalah Bank Muamalat Indonesia (BMI) pada tahun 1991, sebagai hasil kerja Tim Perbankan MUI. Operasionalisasi bank tersebut sejak 1 Mei 1992. Hingga September 1999, BMI telah memiliki lebih lebih dari 45 outlet yang tersebar di Jakarta, Bandung, Semarang, Surabaya, Balikpapan dan Makasar (Bank Muamalat ,1999). Akan tetapi pada awal pendirian BMI, keadaan bank syariah ini belum mendapat perhatian yang optimal dalam tatanan industri perbankan nasional. Landasan hukum operasi bank yang menggunakan sistim syariah ini hanya dikatagorikan sebagai "bank dengan sisitim bagi hasil", tidak terdapat rincian landasan hukum syariah serta jenis-jenis usaha yang diperbolehkan. Hal ini sangat jelas tercermin dari UU no.7 tahun1992, dalam pembahasan perbankan dengan sistim bagi hasil diuraikan hanya sepintas lalu dan merupakan "sisipan" belaka.

\section{PERKEMBANGAN PERBANKAN SYARIAH DI ERA REFORMASI}

Di era reformasi, perkembangan perbankan syariah ditandai dengan disetujuinya UU No.10 Tahun 1998. Dalam Undang-Undang tersebut diatur secara rinci 
landasan hukum serta jenis-jenis usaha yang bsas dioperasikan dan diimplementasikan oleh bank syariah. Undang-undang tersebut juga memberikan arahan bagi bank-bank konvensional untuk membuka cabang syariah atau bahkan mengkonversi diri secara total menjadi bank syariah.

Ternyata kesempatan trsebu $t$ disambut antusias oleh masyarakat perbankan. Beberapa bank mulai memberikan pelatihan dalam bidang perbankan syariah bagi para stafnya. Sebagian bank ingin membuka divisi syariha dalam institusinya, sebagian yang lain berencana mengkonversi diri sepenuhnya menjadi bank syariah. Keadaan demikian kemudian diantisipasi oleh Bank Indonesia dengan mengadakan "Pelatihan Perbanan Syariah" bagi para pejabat Bank Indonesia dari semua bagian, terutama aparat yang terkait langsung seperti Direktorat Penelitian dan Pengaturan Perbankan (DPNP), kredit, pengawasan, akuntansi, riset, dan moneter

Bank pertama milikpemerintah yang melandaskan operasionalnya pada prinsip syariah adalah Bank Syariah Mandiri (BSM). Secara struktural, BSM berasal dari Bank Susila Bakti (BSB), sebagai satu anak perusahaan di lingkup Bank MAndiri (ex BDN), yang kemudian dikonversi menjadi Bank Syariah secara penuh. Untuk melancarkan proses konversi menjadi bank syariah, BSM menjalin kerjasama dengan Tazkia Institute, terutama dalam bidang pelatihan pendampingan konversi.
Satu perkembangan lain perbankan syariah di Indonesia paska reformasi adalah diperkenankannya konversi cabang bank umum konvensional menjadi syariah (Syafeii Antonio,1999). Beberapa bank yang sudah dan akan membuka cabang syariah diantaranya adalah:

1. Bank IFI (membuka cabang syariah pada 28 Juni 1999)

2. Bank Niaga (akan membuka cabang syariah)

3. Bank BNI 46 (telah membuka lima cabang syariah)

4. Bank Mega (akan mengkonversi satu bank konvensional, anak perusahaannya menjadi bank syariah)

5. Bank BTN (akan membuka cabang syariah)

6. Bank BRI (akan membuka cabang syariah)

7. Bank BUKOPIN (sedang melakukan program konversi untuk cabang di Aceh)

8. BPD Jabar (telah membuka cabang syariah di Bandung)

9. BPD Aceh sedang menyiapkan SDM untuk konversi cabang)

\section{KENDALA OPERASIONL PERBANKAN SYARIAH INDONESIA}

Secara operasional perbankan syariah di Indonesia menghadapi kendala yang memerlukan pemecahan.Menurut Arifin (2000) kendala terpenting adalah sebagai berikut:

a. Kurangnya Perangkat Hukum 
Selain Undang-Undang No.7 Tahun 1992 dan Peraturan Pemerintah No.72 Tahun 1992, praktis tak ada pendukung lainnya.Karena inti lembaga keuangan syariah dinilai menurut ukuran konvensional. Ketiadaan perangkat hukum ini menyebabkan perbankan syariah berusaha menyesuaikan produk-produknya dengan hukum yang berlaku. Akibatnya ciriciri khusus yang melekat padanya tersamar dan perbankan syariah tampil seperti perbankan konvensional.

Perangkat hukum yang kurang kondusif juga mengakibatkan konsekuensi lain bagi operasi perbankan syariah. Pada saat terjadi likuiditas misalnya, belum tersedia fasilitas likuiditas tanpa bunga dari Bank Sentral . Ini karena Undang-Undang No. 13 tahun 1968 menegaskan bahwa pendapatan Bank Indonesia adalah berasal dari bunga. Demikian pula untuk menjalankan produkproduk kerjasama antara Bank Indonesia dengan bank syariah yang selalu didasarkan atas tingkat pengembalian yang tetap (fixed), adalah bertentaangan dengan ciri utama bank bagi hasil. Kasus yang sama juga terjadi dalam standar akuntansi yang digunakan.

b. Masalah Sekuritas

Sekuritas merupakan faktor utama di belakang kemajuan di bidang pasar uang dan pasar modal. Pasar tersebut menyediakan suatu alat, yaitu aktiva finansial dapat diperdagangkan guna memobilisasi sumbersuber dana dan menggunakan likuiditas apabila diperlukan. Selama ini surat-surat berharga konvensional yang ada, kecuali saham, berbasis pada sisitim bunga maka bank-bank syariah menghadapi kendala, sebagai akibat mereka tidakdiperbolehkan untuk menjadi bagian dari aktiva dan pasiva yang berbasis bunga.

Masalah ini memberikan dampak yang negatif bagi pengelola likuiditas maupun pengelolaan investasi jangka panjang. Akibatnya mendorong bank syariah memusatkan portofolio mereka pada aktiva jangka pendek yang terkait dengan perdagangan, yang mempunyai dampak berlawanan dengan investasi dan pembangunan ekonomi. Walupun mereka telah berhasil dalam menciptakan pasar bagi perbankan syariah, namun mereka belum mencapai kedalamam pasar yang dapat menjamin kemampuan menghasilkan keuntungan (profitability) dan kelangsungan hiidup (viability) jangka panjang. Mereka tampak masih jauh ketinggalan dalam inovasi tehnik dan pengembangan pasar keuangan, sementara akhir-akhir ini pasar uang dan pasar modal telah berkembang dengan pesat.

Kesempatan pasar telah dikembangkan oleh bank-bank syariah, yang memungkinkan pendanaan dari masyarakat Islam, untuk ditempatkan dalam portofolio yang dibenarkan oleh Islam.Namun sayang belum ada bank syariah yang melakukan investasi besar untuk penelitian dan pengembangan produk, juga belum ada produk keuangan baru yang dikembangkan, terutama dalam derivasi modal yang telah digunakan secara meyakinkan oleh kebanyakan bank syariah. Sehingga kesempatan itu dieksploitasi oleh lembaga keuangan barat yang lebih effisien 
dan inovatif, yang telah dan akan menemukan pasar yang sama.

Kemampuan untuk menjaga kelangsungan hidup jangka panjang bagi bank syariah akan tergantung pada kecepatan, keagresifan, dan keefektifan mereka dalam membangun tehnik dan instrument yang berbasis syariah dan marketable, dengan portofolio yang dilahirkan di negeri Muslim dapat pula dipasarkan di Barat, sebagaiman Barat melakukannya di negeri muslim.

c. Masalah Sumber Daya Insani

Dikotomi antara sistim pendidikan syariah dengan pendidikan umum menyebabkan adanya dualism intelektual antara para ulama dengan sarjan-sarjana muslim,sementara produk perbankan syariah harus diciptakan oleh kedua disiplin tersebut secara bersamasama. Selain itu, masyarakat muslim Indonesia pada umumnya belum familiar dengan praktek perbankan syariah. Sehingga merekapun memandang perbankan syariah denga menggunakan persepsi konvensional.

\section{STRATEGI PENGEMBANGAN PERBANKAN SYARIAH}

Dari kendala-kendala yang dihadapi oleh bank syariah, maka tentunya harus ada upaya pengembangan untuk mengantisipasi kendala tersebut, sehingga nantinya diharapkan bank syariah akan tumbuh makin pesat dan masyarkatpun lebih bias memahaminya. Menurut Arifin (2000) dalam rangka pengembangan perbankan syariah diperlukan pengembangan infrastruktur berupa peraturan perundang-undangan yang mengadopsi prinsip-prinsip syariah,instrument pasar keuangan syariah nasional, serta lembaga penelitian dan pengembangan perbankan syariah yang juga berfungsi sebagai pusat informasi dan pelatihan.

a. Peraturan Perundang-undangan

Undang-undang pebankan syariah diperlukan untuk mengatur prosedur pendirian bank syariah, sistim operasi, ketentuan-ketentuan yang mengatur hak dan kewajiban pelaku-pelaku dalam sisitim perbankan syariah, dan ketentuanketentuan mengenau piranti (instrument) keuangan syariah, termasuk sistim administrasi dan akuntansi.

Dukungan pemerintah terhadap kegiatan ekonomi syariah juga harus diwujudkan dalam program pembangunan. Proyekproyek pemerintah ditata dngan menggunakan mekanisme syariah, terutama yang bertujuan memberdayaka ekonomi usaha kecil dan menengah.

b. Instrumen Pasar Keuangan Syariah

Instrumen pasar keuangan syariah diperlukan untuk mobilisasi dana-dana dan untuk mengatasi kesulitan likuidaitas perbankan syariah apabila diperlukan. Dengan aktifnyainstrumen pasar uang yang berbasisi syariah, maka perbankan syariah dapat melaksanakan fungsinya secara penuh,tidak saja dengan memfasilitasi kegiatanperdagangan jangka pendek,tapi juga berperan dalam mendukung investasi jangka panjang. Struktur keuangan atas proyek-proyek pembangunan berbasis syariah akan 
memperkaya piranti keuangan syariah dan membuka partisipasi lebih besar dari seluruh pelaku pasar, tidak terkecuali non muslim, karena pasar tersebut bersifat terbuka.

c. Dewan Syariah Nasional

Fungsi dari dewan ini adalah mengeluarkan fatwa yang diperlukan sebagai referensi bagi kegiatan operasi dan transaksi serta semua piranti yang diperlukan dalam sistim perbankan syariah. Dewan ini juga berfungsi untuk untuk menjamin agar undang-undang perbankan yang mengadopsi sistim syariah benar-benar dilaksanakan denganprinsip syariah, melakukan audit "kesyariahan" serta memberikan rating syariah atas piranti keuangan syariah, sehingga dapat dikembangkan oleh para pelaku ekonomi dari pasar uang.

d. Litbang dan Pusat Informasi

Lembaga ini sangat diperlukan untuk mengadakan kajian akademis terhadap eonomi syariah juga berfungsi menghilangkan dikotomi intelektual antara para ulama dengan para sarjana ekonomi,sehingga mempermudah mereka dalam memberikan dukungan dalam proses sosialisasi konsep ekonomi syariah. Sosialisasi ini juga bias dilakukan melalui kajian ilmiah di lingkungan akademis dan menjadikannya sebagai wacana perbandingan bagi mahasiswa ekonomi di bidang studi pembangunan.

e. Permodalan
Pembangunan sistim perbanka syariah diperlukan strategi permodalan.Kebutuhan permodalan bagi perbankan syariah dapat dibedakan menjadi dua kategori yaitu modal perusahaan dan modal penyertaanyang memiliki karakterisitik dan resiko yang sama. Modal perusahaan adalah modal permanen yang dicatat sebagai modal setor perusahaan, sedangkan modal penyertaan adalah modal yang bersifat sementara, yaitu penyertaan pihak ketiga dalam investasi yang dapat dijual kepada pihak lain atau dikonversi menjadi modal permanen. Partisipasi modal pemerintah untuk memperbesar pangsa pasar dan peranan perbankan syariah sangat dibutuhka. Partisipasi ini harus merupakan bagian dari rencana pembangunan untuk mendistribusikan kesempatan berusaha, khususnya bagi usaha kecil dan menengah.

f. Pengembangan Jaringan

Beberapa factor penting yang diperlukan sebagai dasar pengembangan jarigan adalah skala pasar, sumber daya insane, sistim dan tehnologi. Dengan salah satu kebijaka yang diperlukan adalah kebijakan otonomi daerah serta adanya meanisme yang dapat mencegah terjadinya aliran dana yang berlebihan ke pusat.

Supaya perbankan syariah dapat lebih menjakau wilayah yang lebih luas, diperlukan adanya keleluasaan untuk membentuk lembaga keuangan regional 
seperti Bank Perkreditan Rakyat Syariah (BPR-S) atau Baitul Mal Tamwil (BMT), memberikan kemudahan bagi bank-bank konvensional untuk melakukan konversi menjadi bank syariah atau mendirikan unit syariah.

\section{KESIMPULAN}

Pengalaman telah benar-benar membuktikan, bahwa dlam keadaa krisis ekonomi yang membuat Negara (Indonesia) terpuruk dalam nilai tukar uang, likuididtas dan kepercayaan sehingga banyak pengusaha besar bangkrut, sedang pengusaha kecil mati, ternyata lembaga keuangan yang masih bias bertahan dan terbukti lepas dari tekanan krisis ekonomi adalah bank yang bberbasis syariah. Bank berbasis syariah tidak memberlakukan sisitim bunga akan tetapi sistim profit and loss sharing atau bagi hasil dan kerugian. Sehingga dalam keadaan krisis suatu perusahaan besar maupun kecil masih bias tetap berlangsung usahanya untuk mendapatkan profit yang diinginkan.

Sejak diberlakukan UU No 7 tahun 1992 dan PP No. 72 tahun 1992, perbankan syariah berkembang dengan cukup pesat, baik lembaga keuangan regional (BPRSyariah,BMT), maupun yang berskala Nasional seperti Bank Mandiri Syariah. Dalam beberapa keadaan perbankan syariah dapat menunjukkan kinerja yang lebih baik. Namun peranan perbankan syariah masih sangat kecil dibandingkan total industry keuangan secara nasional. Hal ini disebabkan karena adanya bebrapa kendala yang menghambat. Sehingga diperlukan suatu strategi yang dapat mengurangi semaksimal mungkin kendala yang sedang dihadapinya.

\section{DAFTAR PUSTAKA}

Ahmad, Imtiyazudin, 1999, "Islamic Banking and Finance The Concept, The Practice and The Challenge", Plain field: The Islamic Society of North America.

Antonio, Muhammad Syafeii, 1999, "Bank Syariah bagi Bankir dan Praktisi Keuangan”, Jakarta: Central Bank of Indonesia and Tazkia Institute.

Antonio , Muhammad Syafeii, 2001, "Bank Syariah dari Teoti ke Praktik", Gema Insani Press, Jakarta 